\title{
ROLE OF FACET JOINT ORIENTATION AND FACET TROPISM IN NONSPESIFIC LOW BACK PAIN
}

\author{
Ezgi Akar, ${ }^{1}$ Aysegul Akdogan Gemici ${ }^{2}$ \\ ${ }^{1}$ Haydarpasa Numune Training and Research Hospital, Department of Neurosurgery, Istanbul, Turkey \\ ${ }^{2}$ Bakirkoy Dr. Sadi Konuk Training and Research Hospital, Radiology Department, \\ Istanbul Bakirkoy, Istanbul, Turkey
}

Primljen/Received 06. 04. 2020. god.

Abstract: Background: Low Back Pain is a complaint at least once we experience all through our life. Although low back pain can be caused by several reasons, mostly low back pain due to nonspecific reasons can be encountered. In this study, our main goal is to examine facet tropism types and facet joint orientation in patients with nonspecific low back pain we have grouped according to age and determine if there is a relationship between the low back pain and facet joint morphology.

Patients and methods: We have retrospectively examined magnetic resonance imaging of 135 patients who applied to the neurosurgery clinic with low back pain complaint in the period of 2017-2018 year. For each phenomenon, facet joint angles have been measured at all vertebra levels. Average values of facet joint angles have been taken and facet orientation has been determined. The difference between right and left facet joint angle has been calculated; degree and type of facet tropism have been determined.

Results: It has been observed that facet joint orientation at L1-2 level was more coronalized in age group of 70-80 when compared to age group of 10-20. 'No type' facet tropism has been observed in majority of the phenomenon and no significant difference has been observed between lumbar levels and age groups.

Conclusion: As a result of our study; it has been concluded that facet joint orientation and facet tropism are not effective in the etiology of nonspecific low back pain. Furthermore, facet tropism is not related to age and maybe it is an inborn characteristic.

Key words: Lumbar vertebra, Low back pain, Magnetic resonance imaging, Facet joint angle, Facet Tropism.

\section{INTRODUCTION}

Low Back Pain (LBP) is a common complaint that occurs at least once in a lifetime and affects more than
Prihvaćen/Accepted 20. 05. 2020. god.

$80 \%$ of the entire population.LBP in women and through elderly age group encountered more frequently ( $>$ 40 age) (1). Plenty of causes are responsible for low back pain. Only below 1\% portion, low back pain encompasses a specific cause (spinal stenosis, lumbar discopathy, infection, compression fracture, spondyloarthritis, radicular pain, cancer, visceral diseases eg) (2). Non-specific causes impactful in vast majority of LBP cases. Among the non-specific causes discogenic and facet joint originated pains while constituted the diagnostic cohort, in one cohort none of any mechanic cause issue may be set forth (3).

Facet joints located over the spine dorsolateral surface refers to diathrodial joint and by the virtue of their complex anatomy and biomechanic features strongly contribute to spinal mechanic functions (4). Movements of facet joints; restricted by their articulations, orientations and capsular outcomes and therefore (facet joints) constraints the rotational movements of vertebra (5). Calculating the right and left facet joint angles average ratios facet joint orientations are determined. In vertebral segment dispersion in between right and left facet joint angles and a facet joint's more sagittal orientation in comparison to an alternative joint has been referred as facet tropism $(5,6)$. Asymmetric orientation in facet joint orientation while observed predominantly in thoracic vertebra not always observed in lumbar vertebra (6). Facet tropism and increased facet joint sagittal orientation are thought to cause intensified axial and rotational compression over the lumbar vertebra, associated with the developments of spinal deformations such as intervertebral disc degeneration, herniation, degenerative spondylolisthesis and scoliosis (7). Degenerative facet joint illness and facet joint osteoarthritis while correlated with chroniclow back pain (8), facet joint orientation and facet tropism 
function in link with low back pain remains unclear. In that present study, among patients segments classified on the basis of age factor with none of any neurosurgical pathology defining the low back pain, reviewing the facet joint orientation and facet tropism types, challenged to find out any association in between the low back pain progression and facet joint morphology.

\section{PATIENTS AND METHODS}

In our study, in between the years of 2016-2018 magnetic resonance imaging (MRI) images of 135 patients applied to our neurosurgery clinic with low back pain complaint and anamnesis records reviewed retrospectively. During the MRI imaging process of the entire cases, the patient was in supine position on the cassette and axial images received in parallel to the end plate. In our study incision criterion consisted of 1) in the age range of 10-80 years of age subject to admittance with backache attack, 2) neurologic detection of the case remaining under normal limits, 3 ) in 2 weeks or longer time period despite pain relief medication use lack of any decrease in pain and pain causing to constraints in daily life events, 4) As per radiologic inspections (X-ray or MRI) having lumbar lordotic preservation of shooting from different angles in normal limits. In our study exclusion criteria; 1) To have been undergone back surgery previously by any cause, 2) In MRI images having any pathology being diagnosed necessitating surgery attempt (lumbar discal hernia, spondylolisthesis, spondylolysis, tumor, scoliosis, fractures, infections, etc), 3) in the case presence of any low back pain leading congenital deformity, muscular, rheumatologic or neurodegenerative disease. MRI images of the cases analysed by two independent persons(one radiologist and one neurosurgeon). For each of the cases, along the entire levels of lumbar vertebra (L1-2, L2-3, L3-4, L4-5, L5-S1) facet joint measurements were made. On each level, mean values of facet joint angles (between the right and left facet joint) were calibrated finding out the facet orientation. Identified method of Norenet al., also used for facet joint angle measurement. For each facet joint; one line was drawn tangential to the superior articular process, and one line was drowned in the midsagittal plane of the vertebra, and the angle between facet joint and the central line has been measured (9). In pursuant to the method put forward by Boden; calculating the dispersion between the right and left joint angles facet tropism grade and its type were found out (5). According to Boden; no facet tropism (FT) with asymmetry in the facet joint orientation as defined difference of the angles between the right and left facet $\leq 6^{\circ}$; mild FT as defined difference of the angles between the right and left facet 6-10E; moderate FT as defined difference of the angles between the right and left facet $11-16^{\circ}$; severe FT as defined difference of the angles between the right and left facet $>16^{\circ}$ (5). In 7 age based diversified groups, along the all vertebral levels mean facet joint angles and facet tropism types were compared with each other.

\section{Statistical analysis}

For statistical analysis NCSS (Number Cruncher Statistical System) 2007 (Kaysville, Utah, USA) program was used. During the evaluation of study data descriptive statistical methods (mean, standard deviation, median, frequency, ratio, minimum, maximum) were applied. Qualitative data normal distribution longitudes were examined by Kolmogorov-Smirnov, Shapiro-Wilk test and graphical assessments. In the comparisons of normal distribution exhibiting three and over three groups One-way Anova Test and in bilateral comparisons Bonferroni test were implemented. Significance at least evaluated on $\mathrm{p}<0.05$ level.

\section{RESULTS}

Applied to neurosurgery clinic with low back pain complaint and as we analysed in MRI inspections out of 135 patients $56.3 \%(n=76)$ were female and $43.7 \%$ $(n=59)$ were male. Ages of the cases varied in the range of 12 and 77, on average corresponds to $45.53 \pm$ 18.07 years of age; among the cases $11.9 \%(n=16)$ remained in 10-20 ages, $11.1 \%(n=15)$ remained in $20-30$ years of age; $20.7 \%(n=28)$ remained in the age of $30-40,14.1 \%(n=19)$ remained in the age of $40-50$; $14.8 \%(n=20)$ remained in the age of 50-60 years of age, $17.0 \%(n=23)$ remained in the age of $60-70$ and $10.4 \%(n=14)$ remained in the age of 70-80 (Table 1$)$. In age based L1-2 levels of the cases, mean FJA measurements revealed a statistically significant weighted variation $(\mathrm{p}=0.031 ; \mathrm{p}<0.05)$ (Figure 1). Searching out to determine the group that leads to dispersion as a

Table 1: Distribution of cases by age and sex

\begin{tabular}{|c|c|c|}
\hline \multirow{4}{*}{ Age (year) } & $\begin{array}{c}\text { Min-Max } \\
\text { (Median) }\end{array}$ & $12-77(44)$ \\
\cline { 2 - 3 } & Mean \pm Std & $45.53 \pm 18.07$ \\
\hline & $\mathbf{1 0 - 2 0}$ & $16(11.9)$ \\
& $\mathbf{2 0 - 3 0}$ & $15(11.1)$ \\
& $\mathbf{3 0 - 4 0}$ & $28(20.7)$ \\
& $\mathbf{4 0 - 5 0}$ & $19(14.1)$ \\
& $\mathbf{5 0 - 6 0}$ & $20(14.8)$ \\
& $\mathbf{6 0 - 7 0}$ & $23(17.0)$ \\
& $\mathbf{7 0 - 8 0}$ & $14(10.4)$ \\
\hline \multirow{2}{*}{ Sex } & Female & $76(56.3)$ \\
& Male & $59(43.7)$ \\
\hline
\end{tabular}


Table 2. Evaluation of mean facet joint angle values at lumbar vertebral levels accor ding to age groups

\begin{tabular}{|c|c|c|c|c|c|c|}
\hline \multicolumn{2}{|c|}{ Age Groups } & FJA L1-2 & FJA L2-3 & FJA L3-4 & FJA L4-5 & FJA L5-S1 \\
\hline \multirow{2}{*}{$\begin{array}{c}10-20^{1} \\
(n=16)\end{array}$} & $\begin{array}{l}\text { Min-Max } \\
\text { (Median) }\end{array}$ & $22-42(29)$ & $23-43(30)$ & $28-46(32)$ & $29-57(40)$ & $28-58(45,5)$ \\
\hline & Mean \pm Std & $30.44 \pm 6.24$ & $30.56 \pm 5.01$ & $34.75 \pm 6.20$ & $41.38 \pm 6.02$ & $45.69 \pm 7.01$ \\
\hline \multirow{2}{*}{$\begin{array}{c}20-30^{2} \\
(n=15)\end{array}$} & $\begin{array}{l}\text { Min-Max } \\
\text { (Median) }\end{array}$ & $15-40(27)$ & $17-40(29)$ & $20-54$ (33) & $24-56(42)$ & $35-50(45)$ \\
\hline & Mean \pm Std & $26.87 \pm 7.02$ & $29.00 \pm 6.73$ & $34.27 \pm 8.09$ & $41.00 \pm 7.91$ & $43.07 \pm 5.28$ \\
\hline \multirow{2}{*}{$\begin{array}{c}30-40^{3} \\
(n=28)\end{array}$} & $\begin{array}{l}\text { Min-Max } \\
\text { (Median) }\end{array}$ & $15-36(25)$ & $15-41(28,5)$ & $18-52(35,5)$ & $20-64(43,5)$ & $36-66(45,5)$ \\
\hline & Mean \pm Std & $25.25 \pm 5.02$ & $29.25 \pm 6.29$ & $35.29 \pm 8.24$ & $42.14 \pm 8.08$ & $47.14 \pm 8.58$ \\
\hline \multirow{2}{*}{$\begin{array}{c}40-50^{4} \\
(n=19)\end{array}$} & $\begin{array}{l}\text { Min-Max } \\
\text { (Median) }\end{array}$ & $17-38(29)$ & $15-42(28)$ & $17-48(34)$ & $31-58(41)$ & $32-66(46)$ \\
\hline & Mean \pm Std & $28.11 \pm 6.15$ & $28.26 \pm 6.10$ & $34.16 \pm 8.37$ & $41.89 \pm 6.66$ & $46.95 \pm 9.61$ \\
\hline \multirow{2}{*}{$\begin{array}{c}50-60^{5} \\
(n=20)\end{array}$} & $\begin{array}{l}\text { Min-Max } \\
\text { (Median) }\end{array}$ & $15-36(25)$ & $19-35(27,5)$ & $26-42(31,5)$ & $20-58(43)$ & $36-65(45,5)$ \\
\hline & Mean \pm Std & $25.05 \pm 5.90$ & $27.55 \pm 5.37$ & $32.15 \pm 5.58$ & $41.40 \pm 8.05$ & $47.40 \pm 7.38$ \\
\hline \multirow{2}{*}{$\begin{array}{c}60-70^{6} \\
(n=23)\end{array}$} & $\begin{array}{l}\text { Min-Max } \\
\text { (Median) }\end{array}$ & $19-40$ (27) & $18-42(27)$ & $22-42(36)$ & $25-53(43)$ & $34-64(45)$ \\
\hline & Mean \pm Std & $26.78 \pm 5.74$ & $28.35 \pm 5.33$ & $34.22 \pm 6.07$ & $41.74 \pm 6.99$ & $46.22 \pm 8.11$ \\
\hline \multirow{4}{*}{$\begin{array}{c}70-80^{7} \\
(n=14)\end{array}$} & $\begin{array}{l}\text { Min-Max } \\
\text { (Median) }\end{array}$ & $15-35(23)$ & $13-41(27,5)$ & $23-43(34,5)$ & $27-53(43)$ & $42-57(49)$ \\
\hline & Mean \pm Std & $23.79 \pm 5.04$ & $26.79 \pm 7.15$ & $32.50 \pm 5.46$ & $41.50 \pm 7.25$ & $49.43 \pm 5.17$ \\
\hline & ${ }^{a} p$ & $0,031 *$ & 0,661 & 0,786 & 0,999 & 0,461 \\
\hline & $\begin{array}{c}\text { Post Hoc test; } \\
{ }_{p}\end{array}$ & $p_{1}>p_{7}$ & - & - & - & - \\
\hline
\end{tabular}

${ }^{a}$ One-way ANOVA Test

${ }^{b}$ Bonferroni Test

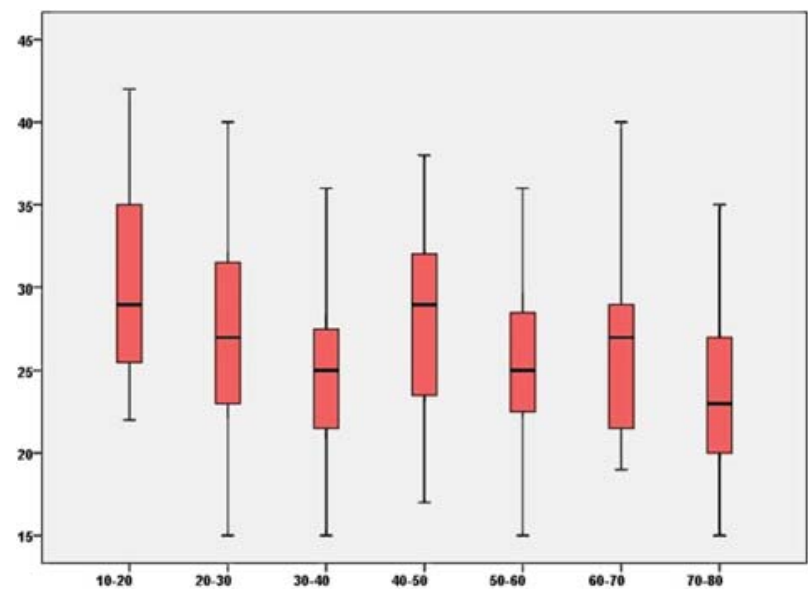

Figure 1. Age based L1-2 level 'mean facet joint angle' measures distribution

result of the performed bilateral comparisons; 10-20 age group cases L1-2 levels mean FJA measurements are higher than 70-80 age group ( $\mathrm{p}=0.047$; $\mathrm{p}<0.05)$. Among the other group's L1-2 levels mean FJA measurements none of statistically weighted diversions was found. Age based L2-3, L3-4, L4-5 and L5-S1 levels of the cases mean facet joint angle calculations are not statistically significant (Table 2). As a result of these data only at L1-2 levels facet joint orientation found to be significantly differented in the age group of 10-20
Table 3. Distribution of Mean facet joint angle values by vertebral levels according to gender

\begin{tabular}{|c|c|c|c|c|}
\hline \multirow{2}{*}{} & \multicolumn{2}{|c|}{$\begin{array}{c}\text { Female Group } \\
\text { FJA }\end{array}$} & \multicolumn{2}{c|}{$\begin{array}{c}\text { Male Group } \\
\text { FJA }\end{array}$} \\
\cline { 2 - 5 } & Mean & Std & Mean & Std \\
\hline L1-2 & 27.4 & 6.2 & 25.4 & 5.5 \\
\hline L2-3 & 29.2 & 5.9 & 27.7 & 5.8 \\
\hline L3-4 & 34.8 & 7.0 & 33.1 & 7.1 \\
\hline L4-5 & 42.6 & 7.7 & 40.4 & 6.3 \\
\hline L5-S1 & 46.0 & 7.5 & 47.4 & 7.8 \\
\hline
\end{tabular}

and in the age group of 70-80 was significantly different and in the age group of 70-80 L1-2 facet joint orientation was monitored to be more coronolized. In the light of other level's mean facet joint angle ratios, based on ages facet joint orientations found not to have had any significant dispersion (Table 2).

On the basis of gender issues when the facet joint angle rates were compared; only at L4-5 levels in between the male and female gender groups found in statistical significance $(\mathrm{p}=0.02 ; \mathrm{p}<0.05)$ and except L5-S1 level in all groups female mean facet joint angle value found higher than male gender and as a result of these figures on female at L4-5 level, facet joint sagitalization found to be more predominant (Table 3, Figure 2). 

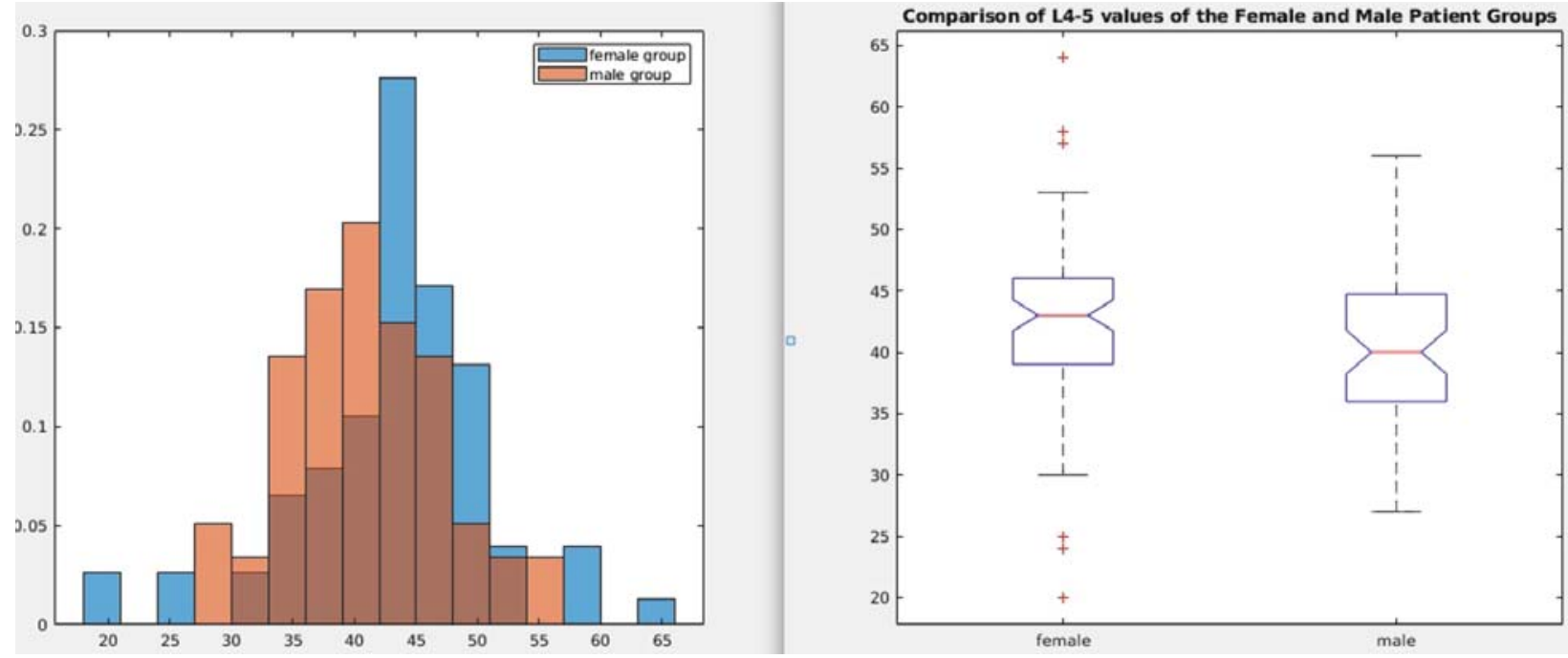

Figure 2. Comparison of L4-5 mean FJA angle values of the male and female patient groups

Table 4. Facet Tropism Types According to Lumbar Vertebral Levels

\begin{tabular}{|c|c|c|c|c|c|c|}
\hline \multirow[b]{2}{*}{ Age Groups } & \multirow[b]{2}{*}{ FT Type } & \multicolumn{5}{|c|}{ Facet Tropism Types According to Lumbar Vertebral Levels } \\
\hline & & $\begin{array}{c}\text { L1-2 } \\
\text { \# of patients }\end{array}$ & $\begin{array}{c}\mathbf{L} 2-3 \\
\text { \# of patients }\end{array}$ & $\begin{array}{c}\text { L3-4 } \\
\text { \# of patients }\end{array}$ & $\begin{array}{c}\text { L4-5 } \\
\text { \# of patients }\end{array}$ & $\begin{array}{c}\text { L5-S1 } \\
\text { \# of patients }\end{array}$ \\
\hline \multirow{4}{*}{$10-20$} & None & $16(100 \%)$ & $13(81 \%)$ & $13(81 \%)$ & $13(81 \%)$ & $11(69 \%)$ \\
\hline & Mild & $0(0 \%)$ & $3(19 \%)$ & $3(19 \%)$ & $1(6 \%)$ & $0(0 \%)$ \\
\hline & Moderate & $0(0 \%)$ & $0(0 \%)$ & $0(0 \%)$ & $2(13 \%)$ & $4(25 \%)$ \\
\hline & Severe & $0(0 \%)$ & $0(0 \%)$ & $0(0 \%)$ & $0(0 \%)$ & $1(6 \%)$ \\
\hline \multirow{4}{*}{ 20-30 } & None & $13(87 \%)$ & $10(67 \%)$ & $11(73 \%)$ & $15(100 \%)$ & $14(93 \%)$ \\
\hline & Mild & $2(13 \%)$ & $5(33 \%)$ & $3(20 \%)$ & $0(0 \%)$ & $1(7 \%)$ \\
\hline & Moderate & $0(0 \%)$ & $0(0 \%)$ & $1(7 \%)$ & $0(0 \%)$ & $0(0 \%)$ \\
\hline & Severe & $0(0 \%)$ & $0(0 \%)$ & $0(0 \%)$ & $0(0 \%)$ & $0(0 \%)$ \\
\hline \multirow{4}{*}{$30-40$} & None & $21(75 \%)$ & $28(100 \%)$ & $28(100 \%)$ & $24(86 \%)$ & $18(64 \%)$ \\
\hline & Mild & $7(25 \%)$ & $0(0 \%)$ & $0(0 \%)$ & $4(14 \%)$ & $7(25 \%)$ \\
\hline & Moderate & $0(0 \%)$ & $0(0 \%)$ & $0(0 \%)$ & $0(0 \%)$ & $2(7 \%)$ \\
\hline & Severe & $0(0 \%)$ & $0(0 \%)$ & $0(0 \%)$ & $0(0 \%)$ & $1(4 \%)$ \\
\hline \multirow{4}{*}{$40-50$} & None & $14(74 \%)$ & $15(79 \%)$ & $16(84 \%)$ & $17(90 \%)$ & $12(63 \%)$ \\
\hline & Mild & $5(26 \%)$ & $3(16 \%)$ & $2(11 \%)$ & $1(5 \%)$ & $6(32 \%)$ \\
\hline & Moderate & $0(0 \%)$ & $1(5 \%)$ & $1(5 \%)$ & $1(5 \%)$ & $1(5 \%)$ \\
\hline & Severe & $0(0 \%)$ & $0(0 \%)$ & $0(0 \%)$ & $0(0 \%)$ & $0(0 \%)$ \\
\hline \multirow{4}{*}{$50-60$} & None & $14(70 \%)$ & $17(85 \%)$ & $17(85 \%)$ & $18(90 \%)$ & $12(60 \%)$ \\
\hline & Mild & $6(30 \%)$ & $2(10 \%)$ & $1(5 \%)$ & $1(5 \%)$ & $4(20 \%)$ \\
\hline & Moderate & $0(0 \%)$ & $1(5 \%)$ & $2(10 \%)$ & $1(5 \%)$ & $2(10 \%)$ \\
\hline & Severe & $0(0 \%)$ & $0(0 \%)$ & $0(0 \%)$ & $0(0 \%)$ & $2(10 \%)$ \\
\hline \multirow{4}{*}{$60-70$} & None & $18(78 \%)$ & $20(87 \%)$ & $20(87 \%)$ & $16(70 \%)$ & $15(66 \%)$ \\
\hline & Mild & $4(17 \%)$ & $2(9 \%)$ & $3(13 \%)$ & $6(26 \%)$ & $4(17 \%)$ \\
\hline & Moderate & $1(5 \%)$ & $1(4 \%)$ & $0(0 \%)$ & $1(4 \%)$ & $4(17 \%)$ \\
\hline & Severe & $0(0 \%)$ & $0(0 \%)$ & $0(0 \%)$ & $0(0 \%)$ & $0(0 \%)$ \\
\hline \multirow{4}{*}{$70-80$} & None & $12(86 \%)$ & $11(79 \%)$ & $10(71 \%)$ & $8(57 \%)$ & $8(57 \%)$ \\
\hline & Mild & $0(0 \%)$ & $1(7 \%)$ & $1(7 \%)$ & $2(14 \%)$ & $3(22 \%)$ \\
\hline & Moderate & $2(14 \%)$ & $2(14 \%)$ & $3(22 \%)$ & $1(7 \%)$ & $2(14 \%)$ \\
\hline & Severe & $0(0 \%)$ & $0(0 \%)$ & $0(0 \%)$ & $3(22 \%)$ & $1(7 \%)$ \\
\hline \multirow{4}{*}{ Total Group } & None & $108(80 \%)$ & $114(84 \%)$ & $115(85 \%)$ & $111(82 \%)$ & $90(67 \%)$ \\
\hline & Mild & $24(18 \%)$ & $16(12 \%)$ & $13(10 \%)$ & $15(11 \%)$ & $25(18 \%)$ \\
\hline & Moderate & $3(2 \%)$ & $5(4 \%)$ & $7(5 \%)$ & $6(4 \%)$ & $15(11 \%)$ \\
\hline & Severe & $0(0 \%)$ & $0(0 \%)$ & $0(0 \%)$ & $3(3 \%)$ & $5(4 \%)$ \\
\hline
\end{tabular}


Upon the assessment of facet tropism type cases; through the entire vertebral levels and along the entire age cohorts 'none type facet tropism' found to be dominant (Table 4). L1-2 level when reviewed based on age groups, "none type facet tropism" found to be at utmost dominant in the age groups of 10-20 years of age. Severe type facet tropism, vast majority having been accumulated in L5-S1 level found to be only on L4-5 and L5-S1 age groups (Table 4).

\section{DISCUSSION}

Low back pain is one of the most frequently met illnesses in daily practice and $70 \%$ of the people experience low back pain at least once in their lifetime. LBP is more frequent in women and through the advanced ages (40-69) its incidence is enhanced, none of any difference has been encountered in terms of its incidence between the rural and urban area (2). Over the vast majority of LBP patients since the pain has gone away spontaneously hospitalization frequency is seldom and most of the hospitalization admittance is detected in women cases (10). Minor age and adolescence low back pains are seldom and in a study incorporated encompassing wide-range of case numbers adolescence low back pains found in $37 \%$ frequency and adolescent low back pains found higher over the girls in comparison with boys (11). During the adolescence and minor age period cases undergone low back pain are anticipated to experience low back pain in aduts (11). In finalized systemic reviews determined low back pains associated risk factors: known as lifting, smoking, obesity, anthropometric measures, posture, depressive symptoms (12). Principally, during the adolescence, psycho-social factors play a significant role in low back pains (13). Low back pain is faced by us due to specific and unspecific underlying factors. Specific underlying factors are known as pathologies impacting the vertebra (epidural abscess, compression fracture, spondyloarthropathy, cauda equine syndrome, discopathy, spinal stenosis, malignity, visceral diseases, eg) (3). Most of the low back pains (90\%) originated from non-specific causes. Whereas nonspecific low back pain may be diversified as diagnosable and non-diagnosable and several structures likewise intervertebral disc and facet joints may be the underlying cause factors (14). Diagnosable group; while progressed in association with facet joint associated pains, sacroiliac pathologies, disco genic issues; non-diagnosable group are progressed depending on psycho-social or other causes and in terms of radiologic detections a pathology is not detected $(2,3)$. In our present research we have analysed the cases with non-diagnosable nonspecific low back pain.

Since low back pain is very often encountered problem; spine surgeons are concentrated on the pre- vention of low back pain, determination of potential risk factors and upon the selection of efficient therapeutic approach. In due course, plenty of studies are present incorporated in association with facet joints.

Final orientations of facet joints; in combination with vertical loading and flexion-extension movements anticipated to be formed during early childhood (15), however, in plenty of researches lifelong remodelling reported to have been sustained (16). Coronal oriented facet joints reported to play role in abundant magnitude of lumbar vertebra pathologies, whereas contrarily sagittalized facet joints reported in wide-spread of studies playing roles in a lot of events such as degenerative spondylolisthesis, spinal stenosis, disc herniation $(16,17)$. Boden et al., have shown that degenerative spinal changes are 25 times more in patients with facet joint sagittal orientation of over 45 degrees (5). From the second decade of life predominantly on intervertebral disc vertebra degenerative processes are launched and low back pain principal cause refers to degenerative causes (18). Emerging in line with advanced age as one of degenerative event facet joint osteoarthritis is one of chronic low back pain cause (18). Kalichmanet et al (12) in between the age and facet orientation principally at L4-5 level found an association and reported the facet's reinforcing potential for sagitalizations subject to age advancements and proved the fact that this case is associated with facet joint osteoarthritis. In our present study, selecting facet joint non-osteoarthritis and non-discopathy cases, we have intended to exclude the low back pain degenerative causes in advance aged cases. In our study; non-facet joint osteoarthritis form diversified based on age levels in non-specific low back pain cases according to lumbar vertebra levels between the facet joint orientations and mean facet joint angle values none of weighted variation was monitored and only in cases in age groups of 70-80 age and 10-20 ages L1-2 level facet joints found in significant difference and again only in age group of 70-80 age L1-2 level facet joints have been found in more coronolized pattern. But, since none of significant dispersions are found in between other levels and age groups; we have aspired that facet joint orientations is not correlated with age factor.

Facet tropism is one of the factors accelerating the development of spinal degeneration $(5,19,20)$. Brailsford (21) defined facet tropism as a more sagittal oriented form of a one side facet joint and as an asymmetry between the right and left facet joint angles. Karacanet al. (22) identified facet tropism, as an angle gauge differentiation over 10 degree between the two of facet joint. In the same study, lumber movement segment facet tropism ratio defined in the range of $14-28 \%$ (22). During the vertebra sagittal movement 
(flexion and extention) zygapophyseal joint of every joint displaced by sliding motion overlapping on each other. One of the each facet joints if placed more closer towards the coronal space prevent front and retro plane movements and cause rotation of vertebra against the facet joint closer to sagittal space (23). Ishihara et al (24) compared the facet joint asymmetry and tropism of adolescents and adults with lumber disc hernia and inthe adolescents found 5 times higher facet joint asymmetry. Some of the researchers suppose that facet tropism may be genetic and not associated with age, gender and ethnic origin (25). In the same way, some of the studies are exist reporting facet joint sagitalization may be progressed with age and therefore also facet tropism is progressed in line with advancing age (26). In our study according to genders we have not determined any significant variation between FT types and in vast majority of the cases we have identified žnone type FT'. Mean facet joint angle values was statistically higher in female gender and at L4-5 level facet orientation was more sagitalized. Moreover, we have identified none of association in between the advancing age and facet tropism development and type.

In literature, none of any studies were found exploring facet tropism role over non-specific low back pain over the cases classified according to ages in which discal pathology or degenerative spinal variations underestimated. In our study FT type of all levels in all patient groups have been found to be at similar frequencies and through the vast majority of cases 'no type FT' was determined.

\section{CONCLUSION}

As a result of our study; as a result of mean facet joint angle measurement only in 70-80 age group in comparison with 10-20 age group L1-2 facet joint angles monitored in more coronalized form. On the other levels and according to ages due to lack of significant dispersion facet joint orientation found to have none of role related to non-specific low back pain. In female gender at L4-5 level mean facet joint angle measurements found to be elevated compared to males. In that circumstance, only concerning L4-5 level facet joint orientation exhibited gender variation and in females, L4-5 facet joints were in a more sagitalized pattern. Additionally, we have supported the fact that FT is not correlated with age and gender and perhaps it is a congenital pattern. In cases with non-specific low back pain without any surgical pathology, it has been proved that there is no cause factor to explain the FT low back pain.

\section{Acknowledgment:None}

Conflict of Interests: The authors declare that there are no conflicts of interest related to this article.

Funding: None

\section{Licensing}

This work is licensed under a Creative Commons Attribution 4.0 International (CC BY 4.0) License.

\title{
Sažetak
}

\section{ULOGA ORIJENTACIJE FASETNIH ZGLOBOVA I FASETNI TROPIZAM KOD NESPECIFIČNOG BOLAU DONJEM DELU LEĐA}

\author{
Ezgi Akar, ${ }^{1}$ Aysegul Akdogan Gemici ${ }^{2}$ \\ ${ }^{1}$ Haydarpasa Numune Training and Research Hospital, Department of Neurosurgery, Istanbul, Turkey \\ ${ }^{2}$ Bakirkoy Dr. Sadi Konuk Training and Research Hospital, Radiology Department, Istanbul Bakirkoy, Istanbul, Turkey
}

Uvod: Bolove u donjem delu leđa smo svi osetili barem jednom u životu. Iako bolovi u donjem delu leđa mogu biti uzrokovani mnogobrojnim faktorima, najčešće se javljaju zbog nespecifičnih razloga. Glavni cilj ove studije bio je da se ispita tip fasetnog tropizma i orjentacija fasetnog zgloba kod pacijenata sa nespecifičnim bolom u donjem delu leđa koje smo grupisali prema godinama i da se utvrdi postoji li veza između bolova u donjem delu leđa i morfologije fasetnog zgloba.

Pacijenti i metode: Retrospektivno smo sagledali nalaze magnetnih rezonanci 135 pacijenata, koji su se javili u Neurohiruršku Kliniku sa bolom u donjem delu leđa u periodu od 2017-2018.te godine. Za svaki feno- men, uglovi fasetnih zglobova su bili mereni na svakom kičmenom pršljenu. Srednja vrednost uglova fasetnih zglobova kao i fasetna orijentacija su bile odredivane. Procenjivana je dalje razlika između levog i desnog ugla fasetnih zglobova, kao i stepen uglova i tip fasetnog tropizma.

Rezultati: Uočeno je da orijentacija fasetnih zglobova na nivou L1-2 je više koronalizovana u starosnoj grupi od 70-80 godina u poređenju sa grupom pacijenata od 10-20 godina. Fasetni tropizam grupe „Bez određenog tipa“ je bio registrovan kod najvećeg broja pacijenata i nije utvrđena značajna statistička razlika između lumbalnih nivoa, niti između starosnih grupa. 
Zaključak: Kao rezultat studije, može se zaključiti da zglobna orijentacija fasetnih zglobova, kao i tropizam fasetnih zglobova nisu efektivni u određivanju etiologije nespecifičnog bola u donjem delu leđa. Šta više tropizam fasetnih zglobova nije povezan sa godi-

\section{REFERENCES}

1. Henschke N, Maher CG, Refshauge KM, Herbert RD, Cumming RG, Bleasel J, et al. Prevalence of and screening for serious spinal pathology in patients presenting to primary care settings with acute low back pain. Arthritis Rheum. 2009; 60(10): 3072-80.

2. Maher C, Underwood M, Buchbinder R. Non-specific low back pain. Lancet. 2017; 389(10070): 736-47.

3. Deyo RA, Rainville J, Kent DL. What can the history and physical examination tell us about low back pain? JAMA. 1992; 268(6): 760-5.

4. An HS, Masuda K, Inoue N. Intervertebral disc degeneration: biological and biomechanical factors. J Orthop Sci. 2006; 11(5): 541-52.

5. Boden SD, Riew KD, Yamaguchi K, Branch TP, Schellinger D, Wiesel SW. Orientation of the lumbar facet joints: association with degenerative disc disease. J Bone Joint Surg Am. 1996; 78(3): 403-11.

6. Varlotta GP, Lefkowitz TR, Schweiter M, Ericco TJ, Spivak J, Bendo JA, et al. Lumbar facet joint: a review of the current knowledge: Part 1: Anatomy, biomechanics, and grading. Skeletal Radiol. 2010; 40(1): 13-23.

7. Chadha M, Sharma G, Arora SS, Kochar V. Association of facet tropism with lumbar disc herniation. Eur Spine J. 2013; 22(5): 1045-52.

8. Jelec V, Turner R, Franic M, Korusic A, Rotim K. Facet orientation and tropism: Association with accelerated degeneration of stabilizing structures in lower lumbar spine. Acta Clin Croat. 2016; 55(1): 117-24.

9. Hirsch C. Etiology and pathogenesis of low back pain. Isr J Med Sci. 1966; 2: 362-70.

10. Global Burden of Disease Study 2013 Collaborators. Global, regional, and national incidence, prevalence, and years lived with disability for 301 acute and chronic diseases and injuries in 188 countries. 1990-2013: a systematic analysis for the Global Burden of Disease Study 2013. Lancet. 2015; 386(9995): 743-800.

11. Swain MS, Henschke N, Kamper SJ, Gobina I, Ottova-Jordan V, Maher CG. An international survey of pain in adolescents. BMC Public Health. 2014; 14: 447.

12. Kalichman L, Suri P, Guermazi A, Li L, Hunter DJ. Facet orientation and tropism: association with facet joint osteoarthritis and degeneratives. Spine. 2009; 34(16): 579-85. nama, što može ukazivati na moogućnost urođenih karakteristika.

Ključne reči: lumbalni pršljenovi, bol u donjem delu leđa, magnetna rezonanca, ugao fasetnih zglobova, tropizam fasetnih zglobova.

13. Kamper SJ, Henschke N, Hestbaek L, Dunn KM, Williams CM. Musculoskeletal pain in children and adolescent. Braz J PhysTher. 2016; 20(3): 275-84.

14. Hancock MJ, Maher CG, Latimer J, Spindler MF, McAuley JH, Laslett M, et al. Systematic review of tests to identify the disc. SIJ or facet joint as the source of low back pain. Eur Spine J. 2007; 16(10): 1539-50.

15. Mahato NK. Facet dimensions, orientation and symmetry at L5-S1 junction in lumbosacral transitional states. Spine. 2011; 36(9): 569-73.

16. Masharawi YM, Alperovitch-Najenson D, Steinberg N, Dar G, Peleg S, Rothschild B, et al. Lumbar facet orientation in spondylolysis: a skeletal study. Spine. 2007; 32(6): 176-80.

17. Wang J, Yang X. Age related changes in the orientation of lumbar facet joints. Spine. 2009; 34(17): 596-8.

18. Quint U, Wilke HJ. Grading of degenerative disk disease and functional impairment: imaging vs patho-anatomical findings. Eur Spine J. 2008; 17(12): 1705-13.

19. Arnoldi CC, Brodsky LE, Cauchoix J, Crock HV, Dommisse GF, Edgar MA, et al. Lumbar spinal stenosis and nerve root entrapment syndromes: definition and classification. Clin Orthop Relat Res. 1976; 115: 4-5.

20. Noren R, Trafimow J, Andersson GB, Huckman MS. The role of facet tropism and facet angle in disc degeneration. Spine. 1991; 16(5): 530-2.

21. Brailsford JH. Deformities of the lumbosacral region of the spine. Br J Surg. 1928; 16: 562-627.

22. Karacan I, Aydin T, Sahin Z, Cidem M, Koyuncu H, Aktas I et al. Facet angles in lumbar disc herniation: their relation to anthropometric features. Spine. 2004; 29(10): 1132-6.

23. Fujiwara A, Tamai K, An HS, Lim TH, Yoshida H, Kurihashi A et al. Orientation and osteoarthritis of the lumbar facet joint. Clin Orthop Relat Res. 2001; 88:94.

24. Ishihara H, Matsui H, Osada R, Ohshima H, Tsuji H. Facet joint asymmetry as a radiologic feature of lumbar intervertebral herniation in children and adolescents. Spine. 1997; 22(17): 2001-4.

25. Pinheiro MB, Ferreira ML, Refshauge K, Ordonana JR ,Machado GC, Prado LR, et al. Symptoms of depression and risk of new episodes of low back pain: a systematic review and meta-analysis. Arthritis Care Res (Hoboken). 2015; 67(11): 1591-603.

26. Kong MH, He W, Tsai YD, Chen NF, Keorochana G, Do DH et al. Relationship of facet tropism with degeneration and stability of functional spinal unit. Yonsei Med J. 2009; 50(5): 624-9.

\section{Correspondence to/Autor za korespondenciju}

Ezgi Akar

Haydarpasa Numune Training and Research Hospital, Department of Neurosurgery

Address: Tibbiye Street, Number 23

34668 Uskudar, Istanbul, Turkey

E-mail: ezgiaycicek@gmail.com

Faxnumber: +90 2163360565 